\title{
Achilles tendon rupture due to distal ureteral stone
}

\author{
Distal üreter taşına bağlı aşil tendon rüptürü \\ Deniz Bolat*, Saadettin Yılmaz Eskiçorapçı**, Semih Akkaya***, Ömer Levent Tuncay** \\ * Doç. Dr. Yaşar Eryılmaz Doğubayazıt Devlet Hastanesi, Üroloji Kliniği, Ağrı \\ ** Pamukkale Üniversitesi, Tıp Fakültesi, Üroloji AD, Denizli \\ *** Pamukkale Üniversitesi, Tıp Fakültesi, Ortopedi ve Travmatoloji AD, Denizli
}

\begin{abstract}
Ureteral stones form the important part of the daily urological practice. Small ureteral stones show tendency to pass with conservative treatments. Such methods as increasing the fluid intake and plyometric exercises are the examples of conservative measures. Herein, we present a case with an achilles tendon rupture due to the plyometric exercises in order to pass $4 \mathrm{~mm}$ distal ureteral stone.
\end{abstract}

Pam Med J 2013;6(1):30-32

Key words: Achilles tendon, plyometric exercise, ureteral stone

\section{Özet}

Üreter taşları güncel üroloji pratiğinin önemli bir kısmını oluşturmaktadır. Küçük üreter taşları konservatif tedavi ile kendiliğinden düşme eğilimindedir. Hidrasyonun artırılması, pleometrik egzersizler gibi yöntemler konservatif yöntemler arasında sayılabilir. Biz burada $4 \mathrm{~mm}$ boyutundaki distal üreter taşını düşürmek için pleometrik egzersize bağlı aşil tendonunda rüptür gelişimini sunduk.

Pam Tip Derg 2013;6(1):30-32

Anahtar sözcükler: Aşil tendonu, pleometrik egzersiz, üreter taşı

\section{Introduction}

Ureteral stones form the $20 \%$ part of whole urinary system stones, and $70 \%$ of these are located in distal ureter [1]. While some of the ureter stones may pass spontaneously with conservative follow-up, some of them may cause urinary tract infection, hydronephrosis and deterioration in renal functions [2]. The patients are recommended by the most of the urologists to increase their fluid intake and jump together with medical expulsive therapies in order to facilitate the expulsion of the stones from ureter. We report a case who had achilles tendon rupture in his right ankle after hard sportive activities requiring explosive power like playing basketball everyday long-term and running, in order to pass his $4 \mathrm{~mm}$ distal ureter stone.

\section{Case Report}

A $4 \mathrm{~mm}$ radio-opacity was seen at the left side of the bone pelvis on KUB graphy of a 39 year old male patient who applied to the urology outpatient clinic with the complaint of left lomber pain (Figure 1). Urinary system ultrasonography revealed minimal hydronephrosis on the left kidney and a $4 \mathrm{~mm}$ hyperechogenity which was compatible with a stone in the left distal ureter.

Conservative treatment was planned for the patient and tamsulosin $0.4 \mathrm{mg}$ capsule once a day was applied as medical expulsive therapy and the patient was adviced to increase his daily fluid intake and to do exercise in order to facilitate the expulsion of the stone. Two weeks after the initiation of the treatment, he was referred to the emergency service with the complaint of severe right ankle pain. The patient

Deniz Bolat

Yazışma Adresi: Doç. Dr. Yaşar Eryılmaz Devlet Hastanesi, Üroloji Kliniği, Doğubeyazıt, Ağrı e-mail: drbolat@hotmail.com 


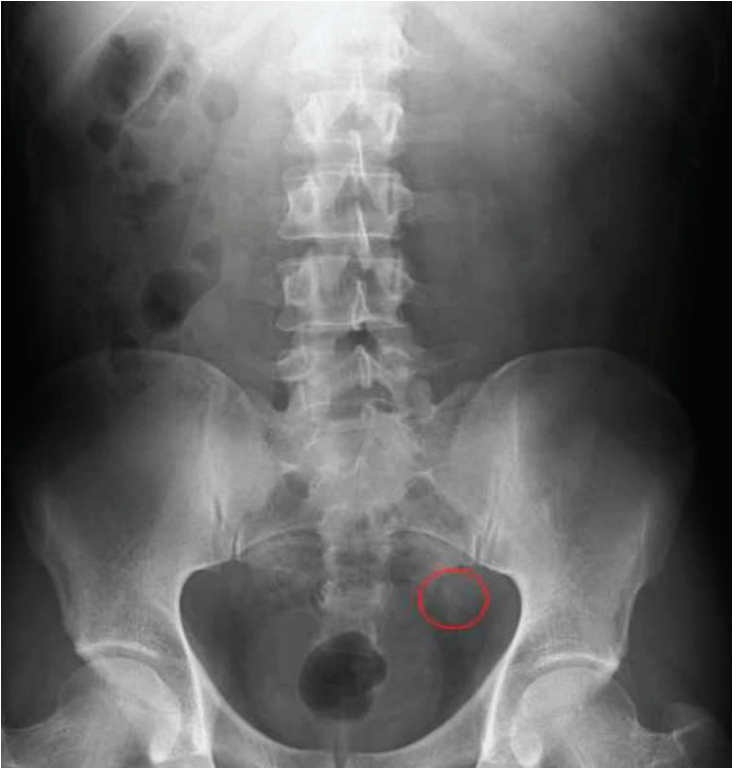

Figure 1. $4 \mathrm{~mm}$ radio-opacity on the direct urinary system graphy of the patient.
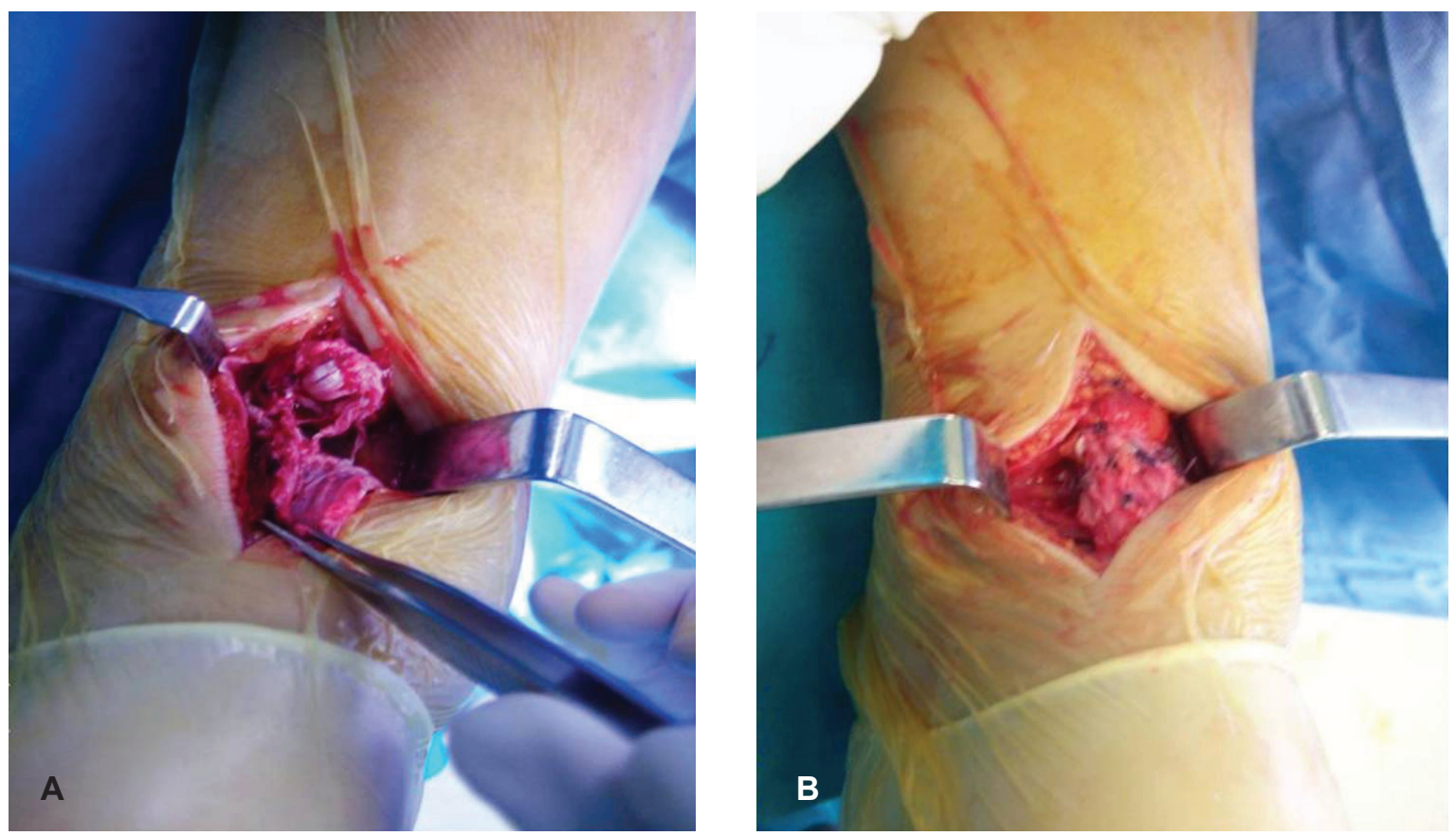

Figure 2. Ruptured right achilles tendon of the patient (A) and its repair (B). 


\section{Discussion}

The treatment modalities in ureteral stones consist of observation (hydration and pain control), medical expulsive therapy (MET), extracorporeal shock wave lithotripsy (ESWL), percutaneous antegrate ureteroscopy, antegrate ureteroscopy and open/laparoscopic ureterolithotomy. It was reported in a metaanalysis that the ratio of spontaneous passage of stones smaller than $5 \mathrm{~mm}$ and stones with a diameter of $5-10 \mathrm{~mm}$ were $68 \%$ and $48 \%$, respectively [3]. Mid and distal ureter stones had higher spontaneous expulsion ratio compared with proximal located ones, regardless from the size. Spontaneous passage rates were reported as $22 \%, 46 \%$ and $77 \%$ for proximal, mid and distal located stones respectively [4]. Increasing the fluid intake, spa-sauna therapies and plyometric exercises may be adviced for the patients together with medical expulsive therapies.

Plyometric training is an intense, advanced form of exercise in which the muscles are first stretched, then contracted (the pre-stretching makes the muscle contract with greater force). Plyometric movements are powerful and highimpact, although the impact should be controlled as much as possible. Plyometric training requires both strength and endurance. Common plyometric training exercises include various jumps and hops, sometimes using obstacles such as steps or cones. These exercises may help to pass the stone by the effect of gravity. The improper plyometric exercises cause sportive injuries such as achilles tendon rupture, meniscus tear or injuries at the vertebral column. While doing plyometric training, the shoes and the ground should be suitable for these exercises and the trainer should perform warm-up exercises before jumping.

Achilles is the thickest tendon of the human body and is formed with the connection of the tendinous parts of gastrocnemius and soleus muscles. Achilles tendon ruptures occur during the sportive activities in the ratio of $44-83 \%$ and these are seen more commonly in males [57]. Achilles tendon rupture is typically seen in third and fourth decades in men who work in the offices and who rarely do exercises [8].

We also observed right achilles tendon rupture in a 39 year old male patient with $4 \mathrm{~mm}$ left distal ureter stone after hard sportive activity requiring explosive power for spontaneous expulsion of the stone.
In conclusion, while suggesting conservative therapies, avoiding from plyometric exercises must be adviced for the patients who are suffering from ureter stones and who have sedentary life and rarely do sportive activities.

Conflict of interest: The authors declared no conflict of interest.

\section{References}

1. Hussain Z, Inman RD, Elwes AW, Shipstone DP, Ghiblawi S, Coppinger SWV. Use of glyceryl trinitrate patches in patients with ureteral stones: a randomized, double-blind, placebo-controlled study. Urology 2001;58:521-525.

2. Hübner WA, Irby P, Stoller ML. Natural history and current concepts for the small ureteral calculi. Eur Urol 1993;24:172-176.

3. Preminger GM, Tiselius HG, Assimos DG, et al. American Urological Association Education and Research, Inc. European Association of Urology. 2007 guideline for the management of ureteral calculi. Eur Urol 2007;52:1610-1631.

4. Morse RM, Resnick MI. Ureteral calculi: natural history and treatment in an era of advanced technology. J Urol 1991;145:263-265.

5. Carden DG, Noble J, Chalmers J, Lunn P, Ellis J. Ruptur of the calcaneal tendon. The early and late management. J Bone Joint Surg 1987;69:416-420.

6. Cetti R, Christensen SE, Ejsted R, Jensen NM, Jorgensen $U$. Operative versus noonoperative treatment of Achilles tendon rupture. Aprospective randomized study and review of the literature. Am J Sports Med 1993;21:791-799.

7. Puddu G, Ippolito E, Postacchini F. A classification of Achilles tendon disease. Am J Sports Med 1976;4: 145-150.

8. Hattrup SJ, Johnson KA. A review of rupture of the Achilles tendon. Foot and Ankle 1985;6:34-38. 